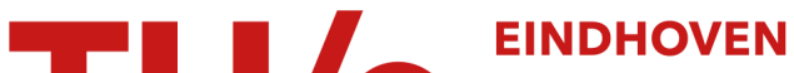 UNIVERSITY OF TECHNOLOGY
}

\section{Factors determining flow rate in chromatographic columns}

Citation for published version (APA):

Cramers, C. A. M. G., Rijks, J. A., \& Schutjes, C. P. M. (1981). Factors determining flow rate in chromatographic columns. Chromatographia, 14(7), 439-444. https://doi.org/10.1007/BF02262882

DOI:

10.1007/BF02262882

Document status and date:

Published: 01/01/1981

\section{Document Version:}

Publisher's PDF, also known as Version of Record (includes final page, issue and volume numbers)

\section{Please check the document version of this publication:}

- A submitted manuscript is the version of the article upon submission and before peer-review. There can be important differences between the submitted version and the official published version of record. People interested in the research are advised to contact the author for the final version of the publication, or visit the $\mathrm{DOI}$ to the publisher's website.

- The final author version and the galley proof are versions of the publication after peer review.

- The final published version features the final layout of the paper including the volume, issue and page numbers.

Link to publication

\section{General rights}

Copyright and moral rights for the publications made accessible in the public portal are retained by the authors and/or other copyright owners and it is a condition of accessing publications that users recognise and abide by the legal requirements associated with these rights.

- Users may download and print one copy of any publication from the public portal for the purpose of private study or research.

- You may not further distribute the material or use it for any profit-making activity or commercial gain

- You may freely distribute the URL identifying the publication in the public portal.

If the publication is distributed under the terms of Article 25fa of the Dutch Copyright Act, indicated by the "Taverne" license above, please follow below link for the End User Agreement:

www.tue.nl/taverne

Take down policy

If you believe that this document breaches copyright please contact us at:

openaccess@tue.nl

providing details and we will investigate your claim. 


\title{
Factors Determining Flow Rate in Chromatographic Columns
}

\author{
C. A. Cramers/J. A. Rijks/C. P. M. Schutjes \\ Laboratory of Instrumental Analysis, Eindhoven University of Technology, P.O. Box 513, Eindhoven, The Netherlands
}

\section{Key Words}

Flow rate

Packed columns

Open tubular columns

Chromatographic permeability

Column resistance factor

\section{Summary}

It is shown that the flow in chromatography is nearly always laminar in nature. Starting from the Darcy equation, expressions are given for the flow rate in both gas and liquid chromatography columns. The concepts of specific permeability, chromatographic permeability and column resistance factor are discussed for packed as well as open tubular columns. The experimental determination of all these factors is demonstrated. The in: fluence of the shape and pore volume of porous and non-porous supports on the column resistance factor and the chromatographic permeability is discussed.

\section{Introduction}

The permeability of a column : determines how much pressure is needed to achieve a given flow rate. Understanding of the flow phenomena in chromatographic columns is of paramount importance since in the practice of chromatography the maximum column inlet pressure that can be applied is often the limiting factor in obtaining more theoretical plates. The scope of this paper is to present a survey of factors determining the macro-flow in packed and open tubular columns for both gas and liquid chromatography. For a more extensive treatment of the subject the reader is referred to the excellent reviews by Deininger [1] and Guiochon [2].

\section{Basic Concepts of Fluid Flow in Chromatographic Columns}

The discussion will be restricted to Newtonian fluids flowing in circular tubes. For Newtonian fluids, as normally encountered in chromatography, the viscosity is independent of rate of shear and constant at a given temperature.

The viscosities of liquids and of gases at pressures normally used are also independent of pressure. They increase with temperature for gases whereas the viscosity of liquids decreases with increasing temperature.

Chromatographic flow is nearly always laminar in nature, seldom molecular or turbulent.

In gas chromatography the flow can be of the molecular or Knudsen type in parts of the column only if the outlet is maintained under a high vacuum as, for example, when a gas chromatographic column is directly connected to the ion source of a mass spectrometer. But even in this case only a very small part at the column end is operating under Knudsen conditions and the overall effect can be neglected [3].

Whether the flow through chromatographic columns is laminar or turbulent depends on the magnitude of the Reynolds number $\mathrm{Re}$, a dimensionless parameter which is given by

$$
\operatorname{Re}=\frac{\rho \mathrm{u}_{\mathrm{m}} \mathrm{d}}{\eta}
$$

where $u_{m}$ is the mobile phase velocity $\left(\mathrm{ms}^{-1}\right)$ averaged over the cross section of the fluid stream as defined later, $\mathrm{d}$ is the tube or particle diameter $(\mathrm{m}), \rho$ is the density $\left(\mathrm{kg} \mathrm{m}^{-3}\right)$ and $\eta$ the dynamic viscosity $\left(\mathrm{Ns} \mathrm{m}^{-2}\right)$ of the mobile phase.

Below a critical value $\operatorname{Re}<\operatorname{Re}_{\text {cr }}$ the flow is laminar.

There are some discrepancies in the literature with respect to the magnitude of $\mathrm{Re}_{\mathrm{cr}}$.

\section{Open Tubular Columns}

For gases and liquids flowing in open tubular columns $\operatorname{Re}_{c r}$ is somewhere between 1500-2300.

From the definition of the Reynolds number it follows that in liquid chromatography the value of $\mathrm{Re}$ and thus the type of flow will be the same at every point in the column.

For gases behaving ideally $\eta$ is independent of pressure. The product of $\rho$ and $u_{m}$ is constant while due to decompression $\rho$ is proportional to and $\mathrm{u}_{\mathrm{m}}$ is inversely proportional to the local pressure.

Thus, the Re number again is constant at any point in the column. This conclusion even holds when the column is 
operated at relatively high pressure gradients. In gas chromatography, Re usually is calculated from

$$
\operatorname{Re}=\frac{\bar{\rho} \overline{\mathrm{u}}_{\mathrm{m}} \mathrm{d}_{\mathrm{c}}}{\eta}
$$

where $d_{c}$ is the internal column diameter, $\vec{u}_{m}$ is the average linear carrier gas velocity and $\bar{\rho}$ the density at the average column pressure, $\overline{\mathrm{p}}$, to be defined in the following. $\operatorname{Re}$ values between 1 and 10 can be expected under operating conditions normally used in both gas and liquid chromatography. This means that the flow in open tubular columns can be considered to be laminar in practically all cases.

\section{Porous Media (Packed Columns)}

Turbulence and the transition from laminar to turbulent flow is not nearly as well defined in packed columns as in open tubes.

Substituting the particle diameter $d_{p}$ in the definition of the $\mathrm{Re}$ number, values between $1<\mathrm{Re}_{\mathrm{cr}}<100$ are quoted for the transition from laminar to turbulent flow.

Under conditions normally encountered in chromatography the flow in packed columns will also always be laminar in nature.

\section{Velocity Definitions}

As shown in Fig. 1, packed columns generally are assumed to be composed of 4 different volume fractions.

Due to the presence of a solid material, only a fraction $\epsilon_{\mathrm{u}}$ of the column volume $\mathrm{V}$ is occupied by the "moving" mobile phase, while a fraction $\epsilon_{i}$ is filled with "stagnant" mobile phase, residing in the pores of the solid particles.

Thus, when discussing flow phenomena it becomes necessary to distinguish between the following frequently used definitions of fluid velocity [4]:

Superficial velocity $u_{s}$

$$
\mathrm{u}_{\mathrm{s}}=\frac{\mathrm{F}}{\mathrm{A}}
$$

where $F$ is the volumetric flow rate at some position in the column and $\mathrm{A}$ is the cross-sectional area of the empty tube. This velocity has no real physical significance for packed columns. For open tubular columns $\epsilon_{\mathrm{i}}=0, \epsilon_{\mathrm{u}}=1$ (the volume fraction $\epsilon_{\mathrm{s}}$ that is occupied by the stationary phase is usually neglected), and the superficial velocity is equal to the mobile phase and unretained component velocities described in the following.

Mobile phase velocity $u_{m}$

$$
\mathrm{u}_{\mathrm{m}}=\frac{\mathrm{F}}{\mathrm{A} \epsilon_{\mathrm{u}}}=\frac{\mathrm{u}_{\mathrm{s}}}{\epsilon_{\mathrm{u}}}
$$

The mobile phase is considered to be moving only in the interparticle volume $\left(\mathrm{V}_{\mathrm{u}}=\epsilon_{\mathrm{u}} \mathrm{V}\right)$ of a packed bed (Fig. 1).

In an open tubular column $\epsilon_{\mathbf{u}}=1$; for packed columns $\epsilon_{\mathrm{u}} \approx 0.4$.

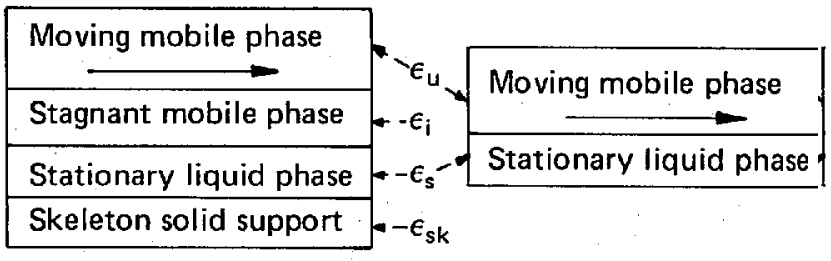

a) Packed column

b) Open tubular column

Fig. 1

Schematic cross sections of chromatographic columns.

$\epsilon_{u}=$ (interparticle) volume fraction of moving mobile phase;

$\epsilon_{\mathbf{i}}=$ (intraparticle) volume fraction of stagnant mobile phase;

$\epsilon_{\mathbf{S}} \quad=$ volume fraction of the stationary liquid;

$\epsilon_{\text {sk }}$. $=$ volume fraction of solid support skeleton.

\section{Linear velocity of an unretained component $u_{M}$}

$$
\mathbf{u}_{\mathrm{M}}=\frac{\mathrm{F}}{\mathrm{A}\left(\epsilon_{\mathbf{u}}+\epsilon_{\mathrm{i}}\right)}=\frac{\epsilon_{\mathrm{u}}}{\epsilon_{\mathrm{u}}+\epsilon_{\mathbf{i}}} \mathbf{u}_{\mathrm{m}}
$$

To an unretained component of small relative molecula mass both the interparticle volume and the complete intra particle pore volume $\left(\mathrm{V}_{\mathrm{i}}=\epsilon_{\mathrm{i}} \mathrm{V}\right)$ of the solid material aft accessible.

For porous particles $\epsilon_{\mathrm{i}} \approx 0.5$. For open tubular columns obviously $\epsilon_{\mathrm{i}}=0$.

Values of $\epsilon_{\mathbf{u}}$ and $\epsilon_{\mathfrak{i}}$ can be measured by non-chromato graphic methods, e.g. by mercury porosimetry. Thest measurements, however are not easily performed.

In practice, $u_{M}$ is found from the column length $L$ and the retention time $t_{M}$ of an unretained component: $u_{M}=L / t_{M}$ In gas chromatography, instead of $u_{M}$ the average velocits $\overline{\mathrm{u}}_{\mathrm{M}}$ will be used, as will be explained later.

\section{Darcy's Law}

As pointed out before, chromatographic flow is nearly always laminar in nature.

Under laminar conditions the total flow through a column is described by Darcy's law (slightly modified to include the dynamic viscosity $\eta$ ):

$$
\mathrm{u}_{\mathrm{m}}=\frac{\mathrm{F}}{\mathrm{A} \epsilon_{\mathrm{u}}}=-\frac{\mathrm{B}}{\eta \epsilon_{\mathrm{u}}} \frac{\mathrm{dp}}{\mathrm{dz}}
$$

which relates mobile phase velocity to the pressure drop $\mathrm{dp} / \mathrm{dz}$, viscosity, interparticle porosity and the specific permeability $\mathrm{B}$. In gas chromatography, $\mathrm{dp} / \mathrm{dz}$ vąries throughout the column length.

As can easily be seen, Darcy's law bears a strong resemblance to the well known Ohm's law.

It should be emphasized that Darcy's law does not yield information about the micro-flow pattern. Only the total flow can be calculated. 
Integration of the Darcy Equation for Liquid

\section{Chromatography}

Since in liquid chromatography $\mathrm{dp} / \mathrm{dz}$ is constant along the column, the Darcy equation can be integrated to:

$$
\Delta \mathrm{p}=\frac{\epsilon_{\mathrm{u}} \eta \mathrm{Lu} \mathrm{u}_{\mathrm{m}}}{\mathrm{B}}
$$

where $\Delta \mathrm{p}=\mathrm{p}_{\mathrm{i}}-\mathrm{p}_{0}$ is the difference between column inlet and column outlet pressures.

This equation can be rewritten as

$$
u_{m}=B \frac{\Delta p}{\epsilon_{u} \eta L}
$$

or

$$
\mathrm{u}_{\mathrm{M}}=\mathrm{B} \frac{\Delta \mathrm{p}}{\eta \mathrm{L}\left(\epsilon_{\mathrm{u}}+\epsilon_{\mathrm{i}}\right)}
$$

As is shown in Fig. 2, a comparison between different packing materials or between packed and open tubular columns can be made by inserting the proper values of $\epsilon_{\mathrm{u}}$, $\epsilon_{\mathrm{j}}$ and $\mathrm{B}$ in this equation.

For open tubular columns, the specific permeability $B$ is given by $d_{c}^{2} / 32$ (Poiseuille [5]).

For packed columns the specific permeability B can be calculated according to the Carman-Kozeny equation [6].

The reader should be aware of the fact that in the literature the Carman-Kozeny equation is quoted both in its original form and in a slightly modified form:

$$
\mathrm{B}=\frac{\mathrm{d}_{\mathrm{p}}^{2}}{180 \psi^{2}} \frac{\epsilon_{\mathrm{u}}^{3}}{\left(1-\epsilon_{\mathrm{u}}\right)^{2}} \quad \text { (original equation) }
$$

or

$$
\mathrm{B}^{*}=\frac{\mathrm{B}}{\epsilon_{\mathrm{u}}}=\frac{\mathrm{d}_{\mathrm{p}}^{2}}{180 \psi^{2}} \frac{\epsilon_{\mathrm{u}}^{2}}{\left(1-\epsilon_{\mathrm{u}}\right)^{2}} \quad \text { (modified equation) }
$$

$\psi^{2} \quad$ is a shape factor

$\psi^{2} \approx 1$ for spherical (glass) beads

$\psi^{2} \approx 1.7$ for porous non-spherical support.

In the practice of chromatography. it is convenient to combine $\mathrm{B}$ and porosities $\epsilon_{\mathrm{u}}$ and $\epsilon_{\mathrm{i}}$ into the so-called chromatographic permeability $\mathrm{B}_{0}$ :

$$
B_{0}=\frac{B}{\epsilon_{u}+\epsilon_{i}}
$$

consequently,

$$
\mathrm{u}_{\mathrm{M}}=\mathrm{B}_{0} \frac{\Delta \mathrm{p}}{\eta \mathrm{L}}
$$

Bristow and Knox [7] suggested the use of a dimensionless quantity, the column resistance factor, $\phi$, defined as:

$$
\phi=\frac{\mathrm{d}_{\mathrm{p}}^{2}}{\mathbf{B}_{\mathbf{0}}}
$$

Substitution of the chromatographic permeability, $B_{0}$, in this equation gives:

$$
\phi=\frac{180 \psi^{2}\left(1-\epsilon_{\mathrm{u}}\right)^{2}\left(\epsilon_{\mathrm{u}}+\epsilon_{\mathrm{i}}\right)}{\epsilon_{\mathrm{u}}^{3}}
$$

Because $\phi$ is independent of the particle diameter, this factor enables comparison of the packing density of columns packed with differently sized particles.

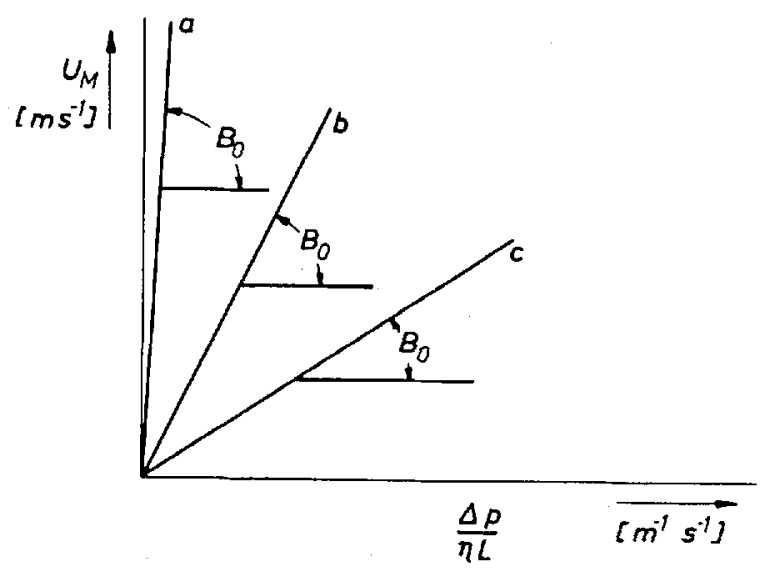

Fig. 2

$u_{M}$ vs $\frac{\Delta p}{\eta L}$ for columns used in liquid chromatography.

Chromatographic permeability $B_{0}\left[\mathrm{~m}^{2}\right]=$ slope.

a open tubular column $\left(d_{C}=10 \mu \mathrm{m}\right)$;

$b$ column packed with spherical non-porous glass beads $\left(d_{p}=10 \mu \mathrm{m}\right)$;

c column packed with angular porous silica $\left(d_{p}=10 \mu \mathrm{m}\right)$.

Values of the various permeabilities $\left(B, B^{*}\right.$ and $\left.B_{0}\right)$ and the column resistance factor $\phi$, calculated according to the equations given in Table I are presented in Table II, for different types of liquid chromatography columns.

It should be noted that the values of $\epsilon_{\mathrm{u}}$ and $\epsilon_{\mathrm{i}}$ used in the calculation are average literature values. Obviously for materials with a porous structure different from the materials as given in Table II (for example GPC packings), the actual values of $\epsilon_{\mathrm{u}}$ and $\epsilon_{\mathrm{i}}$ have to be inserted into the equations. Probably the theoretical values of the column resistance factor $\phi$ vary between 405 for spherical non-porous particles and 1550 for angular porous supports with an intraparticle porosity $\epsilon_{i}$ of 0.5 . For columns packed with impervious glass beads with a particle diameter between $15 \mu \mathrm{m}$ and $100 \mu \mathrm{m}$, column resistance factors of 500 respectively 800 were reported by Schick-Kalb [8]. Knox and Pryde [9] obtained values of $\phi$ of about $500-700$ for spherical silica and its chemically modified derivatives. In a comparative study of column resistance factors between angular and spherical silicas by Unger [10] a difference in resistance factors of roughly a factor of 2 was found (theoretically $\psi^{2}=1.7$ ) It should be emphasized, however, that both types of packing also differ in inter- and intraparticle porosities.

In preparing packed columns it is essential to use a narrow particle size range of the solid support - otherwise smaller particles tend to fill the interparticle volume between the large particles, so that the $\epsilon_{\mathbf{u}}$ values are decreased.

As can be seen from the equation above the column resistance factor $\phi$ will be appreciably increased in this case.

\section{Determination of Permeability and Column Resistance Factor}

Experimental values of the column permeability and the column resistance factor can be obtained fairly easily. From the equations given in Table $I$ it is evident that the 
Table I. Equations commonly used to describe velocity and permeability in packed and open tubular columns for both gas and liquid chromatography

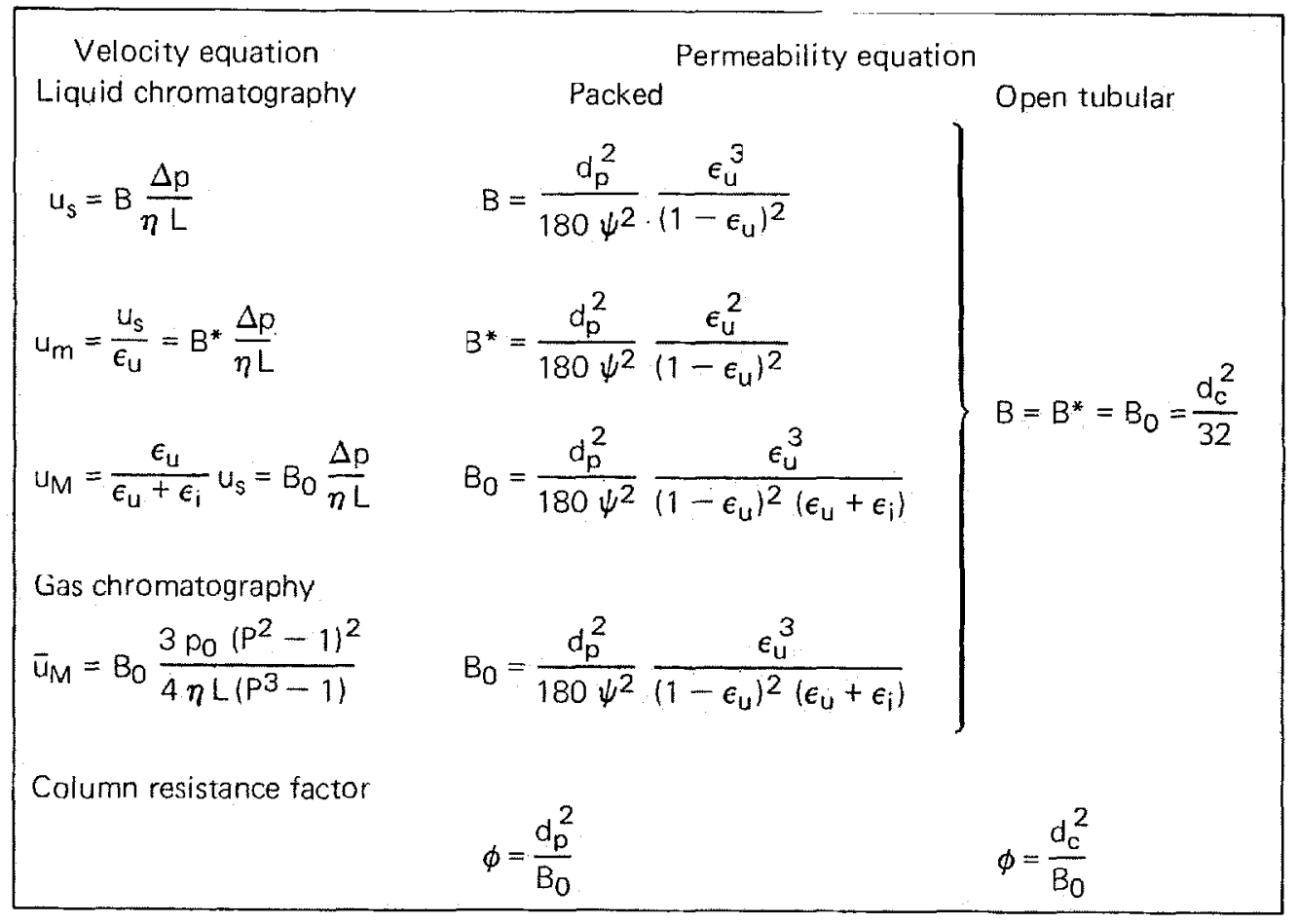

Table II. Theoretical values of specific permeability $B$, chromatographic permeability $\mathrm{B}_{0}$ and column resistance factor $\phi$ in liquid chromatography

\begin{tabular}{|l|c|c|c|}
\hline \multirow{2}{*}{ Property } & \multicolumn{3}{|c|}{ Packed column } \\
\cline { 2 - 4 } & $\begin{array}{c}\text { Non-porous } \\
\text { glass beads }\end{array}$ & $\begin{array}{c}\text { Angular porous } \\
\text { silica }\end{array}$ & $\begin{array}{c}\text { Open tubular } \\
\text { column }\end{array}$ \\
\hline $\begin{array}{l}\text { Particle } \\
\text { size/column } \\
\text { diam. }(\mu \mathrm{m})\end{array}$ & 10 & 10 & 50 \\
$\epsilon_{\mathrm{U}}$ & 0.4 & 0.4 & 1 \\
$\epsilon_{\mathrm{i}}$ & 0 & 0.5 & 0 \\
$\psi^{2}$ & 1 & 1.7 & \\
$\mathrm{~B} \cdot 10^{12}\left[\mathrm{~m}^{2}\right]$ & 0.099 & 0.058 & 78 \\
$\mathrm{~B}_{\mathrm{O}} \cdot 10^{12}\left[\mathrm{~m}^{2}\right]$ & 0.248 & 0.064 & 78 \\
$\phi$ & 405 & 1550 & 32 \\
\hline
\end{tabular}

measurement of a velocity and of the pressure drop across the column is sufficient if column length and mobile phase viscosity are known. Viscosities of mobile phases frequently used in liquid chromatography are listed in table IV.

Example:

for a "reversed phase" column, packed with a chemically modified porous silica $\left(d_{p}=5 \mu \mathrm{m}, \mathrm{L}=15 \mathrm{~cm}\right)$ using an aquous eluate (such as phosphate buffer) and the UV detectable nitrate ion, a $t_{M}$ value of $178 \mathrm{~s}$ is found at a pressure drop of $6.3 \mathrm{MPa}\left(1 \mathrm{MPa}=10^{6} \mathrm{~N} \mathrm{~m}^{-2}=10 \mathrm{bar}\right)$.
Table III. Theoretical values of specific permeability $B$, chromatographic permeability $B_{0}$ and column resistance factor $\phi$ in gas chromatography

\begin{tabular}{|c|c|c|c|}
\hline \multirow[b]{2}{*}{ Property } & \multicolumn{2}{|c|}{ Packed column } & \multirow[b]{2}{*}{$\begin{array}{c}\text { Open tubular } \\
\text { column }\end{array}$} \\
\hline & $\begin{array}{l}\text { Non-porous } \\
\text { glass beads }\end{array}$ & Chromosorb W & \\
\hline $\begin{array}{l}\text { Particle } \\
\text { size/column } \\
\text { diam. ( } \mu \mathrm{m})\end{array}$ & 150 & 150 & 250 \\
\hline$\epsilon_{\mathrm{U}}$ & 0.4 & 0.4 & 1 \\
\hline$\epsilon_{i}$ & 0 & 0.5 & \\
\hline$\psi^{2}$ & 1 & 1.7 & \\
\hline $\mathrm{B} \cdot 10^{12}\left[\mathrm{~m}^{2}\right]$ & 22 & 13 & 1950 \\
\hline $\mathrm{B}_{0} \cdot 10^{12}\left[\mathrm{~m}^{2}\right]$ & 56 & 14 & 1950 \\
\hline$\phi$ & 405 & 1550 & 32 \\
\hline
\end{tabular}

Table IV. Dynamic viscosities [c poise] of mobile liquid phases at $293 \mathrm{~K}$

$\left(1 \mathrm{c}\right.$ poise $\left.=10^{-3} \mathrm{~N} \mathrm{sm}^{-2}\right)$

\begin{tabular}{|ll|ll|}
\hline Water & 1.00 & Benzene & 0.65 \\
Methanol & 0.60 & Cyclohexane & 1.00 \\
Ethanol & 1.20 & Hexane & 0.33 \\
Dichloroethane & 0.79 & Acetonitrile & 0.37 \\
\hline
\end{tabular}


So that

$$
u_{M}=\frac{L}{t_{M}}=\frac{0.15}{178}=8.4 \cdot 10^{-4} \mathrm{~ms}^{-1}
$$

while

$$
\begin{aligned}
\mathrm{B}_{0} & =\mathrm{u}_{\mathrm{M}} \frac{\eta \mathrm{L}}{\Delta \mathrm{p}}=\frac{8.4 \cdot 10^{-4} \cdot 10^{-3} \cdot 0.15}{6.3 \cdot 10^{6}}= \\
& =0.020 \cdot 10^{-12} \mathrm{~m}^{2}
\end{aligned}
$$

and

$$
\phi=\frac{d_{p}^{2}}{B_{0}}=\frac{\left(5 \cdot 10^{-6}\right)^{2}}{0.020 \cdot 10^{-12}}=1250
$$

The differences in $\phi$ when comparing the theoretical value (1550) and the experimental value (1250) can be explained from deviations of the assumed particle shape, the packing technique used and the non uniformity of the particle size distribution.

For a correct measure of $t_{M}$, one must be assured that the unretained component indeed will penetrate the entire pore system of the support material. Obviously the residence time at the interface of the column and the injection and detection system should be negligibly small compared to $t_{M}$, as must be the pressure drop across these extra-column parts. A second and more reliable method for permeability determination, based on velocity measurements as a function of pressure drop is illustrated in Fig. 2. The chromatographic permeability $B_{0}$ is equal to the slope of the straight line resulting from the plot of $u_{M}$ vs $\Delta p / \eta L$. Note that this line should pass through the origin.

For open tubular columns the agreement between experimental and theoretical permeabilities $\left(B_{0}\right)$ and column resistance factors $(\phi)$ is much better. The experimental values generally are very near to the theoretical value, being $d_{c}^{2} / 32$ for the permeability and 32 for the column resistance factor. The small deviations are mainly due to variations of the column diameter along the column.

\section{Integration of the Darcy Equation for Gas Chromatography}

With gases as mobile phases, being compressible media the integration of Darcy's law is necessarily more complex. As the mass flow of the mobile phase is constant at any position $(\mathrm{x})$ in the column for ideal gases under isothermal conditions it follows (Boyle's law)

$$
\mathrm{p}_{\mathrm{x}} \mathrm{u}_{\mathrm{m}(\mathrm{x})}=\mathrm{p}_{0} \mathrm{u}_{\mathrm{m}(0)}
$$

where $p_{0}$ and $u_{m(0)}$ are the pressure and velocity of the carrier gas at the column outlet. Substituting this relation in Darcy's equation gives on integration

$$
\begin{aligned}
\mathrm{u}_{\mathrm{m}(0)} & =-\frac{\mathrm{B}}{2 \epsilon_{\mathrm{u}} \eta \mathrm{L} \mathrm{p}_{0}}\left(\mathrm{p}_{0}^{2}-\mathrm{p}_{\mathrm{i}}^{2}\right) \\
\text { or } \quad & \\
\mathrm{u}_{\mathrm{M}(0)} & =-\frac{B}{2 \epsilon_{\mathrm{u}} \eta L \mathrm{p}_{0}}\left(\mathrm{p}_{0}^{2}-\mathrm{p}_{\mathrm{i}}^{2}\right) \frac{\epsilon_{\mathrm{u}}}{\epsilon_{\mathrm{u}}+\epsilon_{\mathrm{i}}}
\end{aligned}
$$

By definition $P=p_{i} / p_{0}$ is the ratio of inlet to outlet pressure, so that

$$
u_{m(0)}=\frac{B p_{0}}{2 \epsilon_{u} \eta L}\left(P^{2}-1\right)
$$

or

$$
u_{M(0)}=\frac{B p_{0}}{2 \epsilon_{\mathrm{u}} \eta \mathrm{L}}\left(\mathrm{P}^{2}-1\right) \frac{\epsilon_{\mathrm{u}}}{\epsilon_{\mathrm{u}}+\epsilon_{\mathrm{i}}}
$$

Chromatographia Vol. 14 No. 7, July 1981
In their first publication on gas chromatography James and Martin [11] have already shown that the outlet velocity $u_{m(0)}$ is related to the time average velocity $\bar{u}_{m}$ (velocity at the average column pressure $\overline{\mathbf{p}}$ ) by:

$$
\begin{gathered}
\overline{\mathrm{u}}_{\mathrm{m}}=\gamma \mathrm{u}_{\mathrm{m}(0)} \\
\overline{\mathrm{p}}=\frac{\mathrm{p}_{0}}{\gamma}
\end{gathered}
$$

where

$$
\gamma=\frac{3}{2} \frac{\mathrm{P}^{2}-1}{\mathrm{P}^{3}-1}
$$

In gas chromatography the average velocity $\bar{u}_{M}$ is found from the retention time of an unretained component $t_{M}$ and the column length:

$$
\overline{\mathrm{u}}_{\mathrm{M}}=\frac{\mathrm{L}}{\mathrm{t}_{\mathrm{M}}}=\gamma \mathrm{u}_{\mathrm{M}(0)}
$$

This leads to the equation:

$$
\overline{\mathrm{u}}_{\mathrm{M}}=\frac{3}{4} \frac{\mathrm{B} \mathrm{p}_{0}}{\eta \mathrm{L}\left(\epsilon_{\mathrm{u}}+\epsilon_{\mathrm{i}}\right)} \frac{\left(\mathrm{P}^{2}-1\right)^{2}}{\mathrm{P}^{3}-1 .}
$$

Again the chromatographic permeability $B_{0}$ is defined as

$$
\mathrm{B}_{0}=\frac{\mathrm{B}}{\epsilon_{\mathrm{u}}+\epsilon_{\mathrm{i}}}
$$

giving:

$$
\overline{\mathrm{u}}_{\mathrm{M}}=\mathrm{B}_{0} \frac{3 \mathrm{p}_{0}\left(\mathrm{P}^{2}-1\right)^{2}}{4 \eta \mathrm{L}\left(\mathrm{P}^{3}-1\right)}
$$

Experimental data for the chromatographic permeability can be obtained in a similar way as shown skip above already for liquid chromatography by inserting the retention time of an unretained substance and the column inlet and outlet pressures in the equation above. Moreover, the column length and carrier gas viscosity must be known. Viscosity data of carrier gases currently used are presented in Table V.

Alternatively, the chromatographic permeability also can be found from velocity measurements at differing column inlet pressures. As shown in Fig. 3 , in this case $B_{0}$ is equal to the slope of the straight line that can be fitted through the data points when $\overline{\mathrm{u}}_{\mathrm{M}}$ is plotted versus:

$$
\frac{3}{4} \frac{\mathrm{p}_{0}}{\eta \mathrm{L}} \frac{\left(\mathrm{P}^{2}-1\right)^{2}}{\left(\mathrm{P}^{3}-1\right)}
$$

Table V. Dynamic viscosities [ $\mu$ poise] of mobile gaseous phases at different temperatures $\left(1 \mu\right.$ poise $\left.=10^{-7} \mathrm{~N} \mathrm{sm}^{-2}\right)$

\begin{tabular}{|l|c|l|l|l|l|}
\hline Carrier gas & $293 \mathrm{~K}$ & $373 \mathrm{~K}$ & $473 \mathrm{~K}$ & $573 \mathrm{~K}$ & $673 \mathrm{~K}$ \\
\hline $\mathrm{H}_{2}$ & 87 & 103 & 121 & 139 & 154 \\
$\mathrm{He}$ & 194 & 229 & 270 & 307 & 342 \\
$\mathrm{~N}_{2}$ & 175 & 208 & 246 & & 311 \\
$\mathrm{CO}_{2}$ & 148 & 185 & 229 & 268 & \\
$\mathrm{H}_{2} \mathrm{O}$ (vapour) & & 128 & 166 & 201 & 235 \\
$\mathrm{Ar}$ & 221 & 269 & 322 & 368 & 411 \\
Isobutane & 74 & & & & \\
\hline
\end{tabular}


In Table III calculated values of permeabilities $\left(B, B_{0}\right)$ and the column resistance factor $\phi$ are presented for several gas chromatography columns. The equations used for calculating these values are listed in Table $I$ and are the same as used in the case of liquid chromatography. In gas chromato. graphy the prediction of column inlet pressure from a

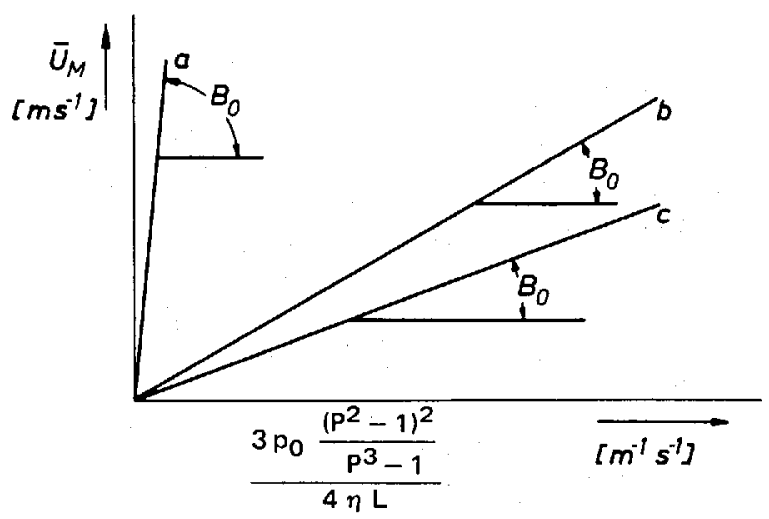

Fig. 3

$\bar{u}_{M}$ vs $\frac{3 p_{0}}{4 \eta L} \frac{\left(P^{2}-1\right)^{2}}{\left(P^{3}-1\right)}$ for columns used in gas chromatography.

Chromatographic permeability $B_{0}\left[m^{2}\right]=$ slope.

a open tubular column $\left(d_{c}=250 \mu \mathrm{m}\right)$;

$b$ micropacked column $\left(d_{c}=0.8 \mathrm{~mm} ; d_{p}=150 \mu \mathrm{m}\right)$;

$c$ packed column $\quad\left(d_{c}=4 \mathrm{~mm} ; d_{p}=150 \mu \mathrm{m}\right)$.

(Packing ( $b$ and $c$ ) spherical glass beads.)

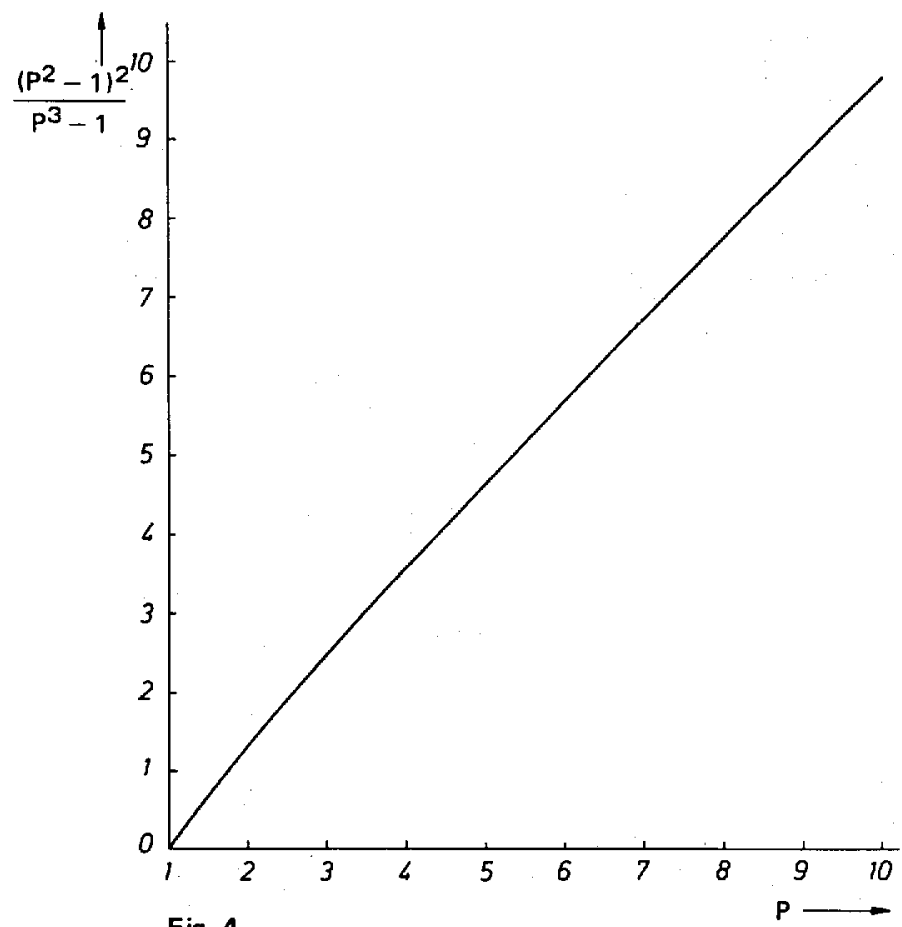

Fig. 4

$$
\frac{\left(P^{2}-1\right)^{2}}{P^{3}-1} \text { vs } P=\frac{P_{i}}{P_{0}}
$$

theoretically calculated permeability value is not as easy as for liquid chromatography, as may be clear from the follow. ing example:

for a capillary colum $\left(\mathrm{L}=50 \mathrm{~m}\right.$, i.d. $=0.25 \mathrm{~mm}, \mathrm{~T}=200^{\circ} \mathrm{C}$ using $\mathrm{He}$ as the carrier gas an average linear velocity of $20 \mathrm{cms}^{-1}$ is normally required. At atmospheric outlet pressure $\left(1 \mathrm{bar}=10^{5} \mathrm{~N} \mathrm{~m}^{-2}\right)$

$$
\begin{aligned}
& \overline{\mathrm{u}}_{\mathrm{M}}=0.20 \mathrm{~m} \mathrm{~s}^{-1} \\
& \mathrm{~B}_{0}=\frac{\mathrm{d}_{\mathrm{c}}^{2}}{32}=1950 \cdot 10^{-12} \mathrm{~m}^{2} \\
& \frac{\left(\mathrm{P}^{2}-1\right)^{2}}{\left(\mathrm{P}^{3}-1\right)}=\frac{4 \eta \mathrm{L} \overline{\mathrm{u}}_{\mathrm{M}}}{3 \mathrm{~B}_{0} \mathrm{P}_{0}}=\frac{4 \cdot 270 \cdot 10^{-7} \cdot 50 \cdot 0.20}{3 \cdot 1950 \cdot 10^{-12} \cdot 10^{5}}=1.85
\end{aligned}
$$

As can be seen from Fig. 4, this value of $\frac{\left(\mathrm{P}^{2}-1\right)^{2}}{\left(\mathrm{P}^{3}-1\right)}=1.85$ corresponds to $\mathrm{P}=\frac{\mathrm{p}_{\mathrm{i}}}{\mathrm{p}_{0}}=2.47$, thus the required columt inlet pressure will be 2.47 bar and the pressure drop acrosi the columns is 1.47 bar.

For the same reasons already discussed for packed columns in liquid chromatography, the theoretical permeability values for gas chromatographic columns given in Table III may not be highly accurate. For the interparticle volume $\epsilon_{\mathrm{u}}$, a value of 0.4 is used in the calculations, whereas actual $\epsilon_{\mathrm{u}}$ values between 0.36 and 0.45 are reported by Guiochon [2] for various packing materials. Actual values of the intra particle porosity $\epsilon_{\mathrm{i}}$ may also appreciably deviate from the assumed value of 0.5 .

\section{Note}

In a recent article [12] Ohmacht and Halász present data on inter- and intra-particle porosities for 18 commercially available silicas for HPLC.

\section{References}

[1] G. Deininger, Ber. Bunsenges. 77, 145 (1973).

[2] G. Guiochon, "Chromatographic Reviews", Vol. 8, Elsevie Publishing Co., Amsterdam, 1966.

[3] C.A.Cramers, G. J. Scherpenzeel and P. A. Leclercq, J. Chromatogr. 203, 207 (1981).

[4] J. C. Sternberg and R.E. Poulson, Anal. Chem. 36, 58 (1964).

[5] J. L. M. Poiseuille, C.R. 11 (1840): Mem. des Savant Etrang. 9 (1846).

[6] J. Kozeny, Ber.d. Wiener Akad. Abt. 11a, 36, 271 (1927).

[7] P. A. Bristow and J.H. Knox, Chromatographia 10, 279 (1976).

[8] J. Schick-Kalb, in "Porous Silica", K. K. Unger, Elsevie Scientific Publishing Co., Amsterdam, 1979, p. 181.

[9] J.H. Knox and A.Pryde, J. Chromatogr. Sci. 10, 606 (1972).

[10] K. K. Unger and W. Messer, J. Chromatogr. 149, 1 (1978).

[11] A. T. James and A. J. P. Martin, Biochem. J. 50, 679 (1952).

[12] R. Ohmacht and J. Halasz, Chromatographia 14, 155 (1981).

Received: Jan. 20, 1981 Accepted: Jan: 22, 1981 B 